Article

\title{
Development of a Novel Shaft Dryer for Coal-Based Green Needle Coke Drying Process
}

\author{
Guowei Xie ${ }^{1,2}$, Xinxin Zhang ${ }^{1}$, Jiuju Cai ${ }^{3,4}$, Wenqiang Sun ${ }^{3,4, *} \mathbb{C}$, Ketao Zhang ${ }^{2}$ \\ and Shiyu Zhang ${ }^{2}$ \\ 1 School of Energy and Environmental Engineering, University of Science and Technology Beijing, \\ Beijing 100083, China \\ 2 Sinosteel Anshan Research Institute of Thermo-Energy Co., Ltd., Anshan 114044, Liaoning, China \\ 3 Department of Thermal Engineering, School of Metallurgy, Northeastern University, \\ Shenyang 110819, Liaoning, China \\ 4 State Environmental Protection Key Laboratory of Eco-Industry, Northeastern University, \\ Shenyang 110819, Liaoning, China \\ * Correspondence: sunwq@mail.neu.edu.cn
}

Received: 22 July 2019; Accepted: 8 August 2019; Published: 12 August 2019

Featured Application: The energy efficient and environmentally friendly shaft dryer can be applied for drying green cokes during the needle coke production process.

\begin{abstract}
The industry of coal-based green needle coke develops rapidly in recent years. The green coke produced by the delayed coking process usually has a moisture content of $10 \%-25 \%$, which damages the calcining kiln and needle coke quality. A standing dehydration tank is currently used to reduce the moisture content of green coke. However, this process has several weaknesses such as unstable operation, large land area occupation, and low productivity. To solve this issue, a novel drying system with a shaft dryer proposed in this work is suitable for green coke drying. Moreover, the performances of the green coke are investigated to design the proposed shaft dryer. The experimental result shows that the average vertex angle of the pile of green cokes is $109.2^{\circ}$. The pressure drop of the dryer increases linearly with the green coke bed height, and the green coke with a larger size has a smaller pressure drop. The specific pressure drops are 5714, 5554, 5354, and $5114 \mathrm{~Pa} / \mathrm{m}$, with median green coke sizes of $26.85,29.00,30.45$, and $31.80 \mathrm{~mm}$, respectively. Tooth spacing is another important parameter which influences the mass of green coke leakage. The optimal tooth spacing and rotary speed of the rollers are determined by the required production yield.
\end{abstract}

Keywords: green coke; coal-based needle coke; shaft dryer; drying process

\section{Introduction}

Needle coke, as an important carbon material, can be classified into two types, i.e., petroleum-based needle coke [1] with heavy oil as the raw materials, and coal-based needle coke [2] with coal tar, coal pitch, or their fractions as the raw materials. Initially, petroleum-based needle coke occupies the dominant position, while the production of coal-based needle coke is greatly accelerated due to the high price and lightening production of petroleum in the recent years.

Green manufacturing and cleaner production [3] have become one prominent feature of sustainable development. Especially in the context of carbon trade and carbon tax [4,5], energy conservation and emissions reduction are definitely the key issues of various industrial processes, such as ceramic production [6], ironmaking [7], sintering [8], and power generation [9]; and the needle coke drying process should be no exception. Coal-based needle coke is a perfect material for the manufacturing of 
the ultra-high-power electrode used in the compact steelmaking process. Iron and steel are traditionally produced with iron ores as material inputs and coal-based energies as energy inputs [10], which has a high energy consumption and heavy environmental pollution [11]. Contrarily, the compact steelmaking process using scrap as the main material input and electricity as the main energy source attracts more and more attraction [12]. Coal-based needle coke also serves as anode materials of lithium-ion batteries. The use of ultra-high-power electrode made from coal-based needle coke can reduce the smelting time by $10 \%$ to $20 \%$, resulting in the electrode consumption and electricity consumption. In addition, with the rapid development of lithium-ion battery [13], the demand for anode materials increases obviously, which results in the mushroom of green coke of coal-based needle coke [14].

The production of coal-based needle coke consists of three main processes: pretreatment of raw materials, delayed coking [15], and calcining [16]. The coke produced by a delayed coking process is called green needle coke, while called calcined needle coke if produced by a calcining process. For the coking process, the size of dust emissions is mainly 3.3 to $9.0 \mu \mathrm{m}$, and the main chemical components are $\mathrm{C}, \mathrm{SiO}_{2}, \mathrm{Al}_{2} \mathrm{O}_{3}, \mathrm{~S}, \mathrm{CaO}$, and $\mathrm{TFe}$, with contents of $76.30 \%-81.30 \%, 5.36 \%-5.91 \%, 3.96 \%-4.26 \%$, $1.15 \%-1.34 \%, 0.52 \%-1.59 \%$, and $0.81 \%-1.34 \%$, respectively [17]. Green coke serves as the material input of the calcining process, and its drying degree directly affects the energy consumption and the quality of the final product of the calcining process. The green coke discharged from the delayed coking unit has a moisture content of $10 \%$ to $25 \%$. If the green coke with such a high moisture content enters the rotary kiln to be calcined, the following negative aspects will occur from whole system and life cycle perspectives [18]: (i) the temperature of the kiln tail will be lower, and the parameters such as kiln pressure, air amount, and fuel ratio have to be adjusted frequently, which will cause difficulty in operating the rotary kiln; (ii) more thermal energy will be consumed [19] in the calcining process; and (iii) there is a greater possibility of being exploded to scraps, compared with green coke with low moisture content, resulting in small particle size of calcined coke.

To reduce the moisture content of green coke, several standing dehydration tanks are usually used in the real-world production process to maintain the moisture content of green coke below $5 \%$ in 5 days. But in winter, the water escapes slower from the coke surface and internal pores [20], then the moisture content may reach $8 \%$ due to the low temperature, which results in an unstable operation of the rotary calcining kiln, and further affects the energy consumption and calcined coke quality. In addition, the dehydration tanks, with a height of approximately $10 \mathrm{~m}$ and a diameter of 2 to $4 \mathrm{~m}$, and the large inclination belt conveyor occupy a large land area with a resultant capital investment cost. Thus, a new drying system should be developed to accelerate the drying process and stabilize the final moisture content of green cokes.

Several drying methods are widely used in high energy-consuming industrial processes [21], including rotary dryer [22,23], tubular drier [24], airflow dryer [25], fluidized-bed dryer [26], and microwave dryer [27]. Table 1 summarizes the characteristics of the drying methods mentioned in previous studies when they used for drying green coke. It is indicated that the dryers widely used in other industries are not suitable for green coke drying. Given the advantageous material flow and heat transfer of shaft facilities [28-30], this work aims at designing a novel efficient drying system with a shaft dryer that is suitable for green coke drying, with sound energy usage [31] and low environmental impact [32,33]. In addition, key characteristics of the green coke, including particle size distribution [34], initial moisture content, vertex angle, pressure drop scheme [35], and the discharge characteristics, are essential to determine the parameters of the designed dryer [36]. However, little information can be found on this topic. This work investigates these characteristics experimentally and provides detailed data that are important to design the proposed shaft dryer for drying green coke. 
Table 1. Comparison of different green coke drying methods.

\begin{tabular}{|c|c|c|c|c|c|c|c|}
\hline Method & Advantage & Disadvantage & $\begin{array}{l}\text { Operation and } \\
\text { Maintenance }\end{array}$ & $\begin{array}{l}\text { Quality of } \\
\text { Green Coke }\end{array}$ & $\begin{array}{l}\text { Energy } \\
\text { Efficiency } \\
(\%)\end{array}$ & Productivity & $\begin{array}{c}\text { Capital } \\
\text { Investmen } \\
\text { Cost }\end{array}$ \\
\hline $\begin{array}{l}\text { standing } \\
\text { dehydration } \\
\text { tank }\end{array}$ & $\begin{array}{l}\text { simper tank structure; low energy } \\
\text { consumption; high safety }\end{array}$ & $\begin{array}{l}\text { uneven drying effect; low drying } \\
\text { efficiency; unstable moisture content; } \\
\text { large area occupied; high capital } \\
\text { investment cost }\end{array}$ & easy & $\begin{array}{c}\text { unstable } \\
\text { moisture content }\end{array}$ & - & medium & high \\
\hline rotary dryer & $\begin{array}{l}\text { good drying effect; wide } \\
\text { applicability; easy to achieve } \\
\text { mechanization and automation; } \\
\text { good uniformity of green coke; } \\
\text { simple operation }\end{array}$ & $\begin{array}{l}\text { multiple transmission components of } \\
\text { the dryer, which need continual } \\
\text { running repairs; large device, large } \\
\text { area occupied, high capital investment } \\
\text { cost; serious burning loss of green coke }\end{array}$ & difficult & $\begin{array}{l}\text { easily polluted } \\
\text { and over-burnt }\end{array}$ & $50-60$ & high & high \\
\hline tubular drier & $\begin{array}{l}\text { sound safety; light abrasion of } \\
\text { green coke }\end{array}$ & $\begin{array}{l}\text { crushing is needed to meet the } \\
\text { requirement on green coke particle size; } \\
\text { poor drying effect; high failure rate of } \\
\text { the dryer }\end{array}$ & difficult & serious breakage & $30-40$ & low & medium \\
\hline airflow dryer & $\begin{array}{l}\text { short drying time; good drying } \\
\text { effect; big drying capacity; simple } \\
\text { dryer structure, small area } \\
\text { occupied; easy for manufacture; } \\
\text { low capital investment cost }\end{array}$ & $\begin{array}{l}\text { high energy consumption; poor safety; } \\
\text { serious dryer wear, short service life; } \\
\text { refractory waste gas; crushing is } \\
\text { needed to meet the requirement on } \\
\text { green coke particle size }\end{array}$ & moderate & serious breakage & $60-75$ & high & low \\
\hline $\begin{array}{l}\text { fluidized-bed } \\
\text { dryer }\end{array}$ & $\begin{array}{l}\text { big drying capacity; simple dryer } \\
\text { structure }\end{array}$ & $\begin{array}{l}\text { wall accretion and bed blocking easily } \\
\text { occur; serious dust entrainment in } \\
\text { waste gas; uneven drying of green } \\
\text { coke; crushing is needed to meet the } \\
\text { requirement on green coke particle size }\end{array}$ & easy & serious breakage & $50-60$ & high & medium \\
\hline $\begin{array}{l}\text { microwave } \\
\text { dryer }\end{array}$ & good drying effect & $\begin{array}{l}\text { underdeveloped technology; } \\
\text { high electricity consumption; } \\
\text { safety concerns }\end{array}$ & easy & good & $25-35$ & low & high \\
\hline
\end{tabular}




\section{Design of the Novel Drying System and Shaft Dryer}

To overcome the shortcomings of currently used dryers for drying green coke, this work proposes a novel drying system, as shown in Figure 1. The proposed drying system consists of 10 main components: primary air blower, secondary air blower, combustion chamber, hot stove, belt conveyor, shaft dryer, helical conveyor, bucket elevator, transfer hopper, and exhaust fan. Fuel gas and the air from primary air blower are mixed and fired in the combustion chamber. The generated high-temperature flue gas at $1300^{\circ} \mathrm{C}$ is sent to the hot stove, inside which the high-temperature flue gas is mixed with the low-temperature air from the secondary air blower to get the medium-temperature gas at 450 to $500{ }^{\circ} \mathrm{C}$. The medium gas is then piped into the bottom of the shaft dryer. A constant feeder discharges the wet green cokes to a belt conveyor, through which the wet green cokes are transferred to the top hopper of the shaft dryer at a constant speed. Next, the wet green cokes are fed into the dryer uniformly to exchange heat with the medium-temperature gas in an energy-efficient, direct-contact, and counter-current way [37]. The discharging unit at the bottom of the shaft dryer controls the discharge speed and loosens the green cokes to prevent blocking the dryer. The discharged final green cokes enter a helical conveyor and are then conveyed to a bucket elevator, which connects the inlet of a transfer hopper. When the temperature of the green cokes is lower than $70{ }^{\circ} \mathrm{C}$, the final product is packaged. The waste gas from the shaft dryer is treated via a bag filter before emitted into the atmosphere.

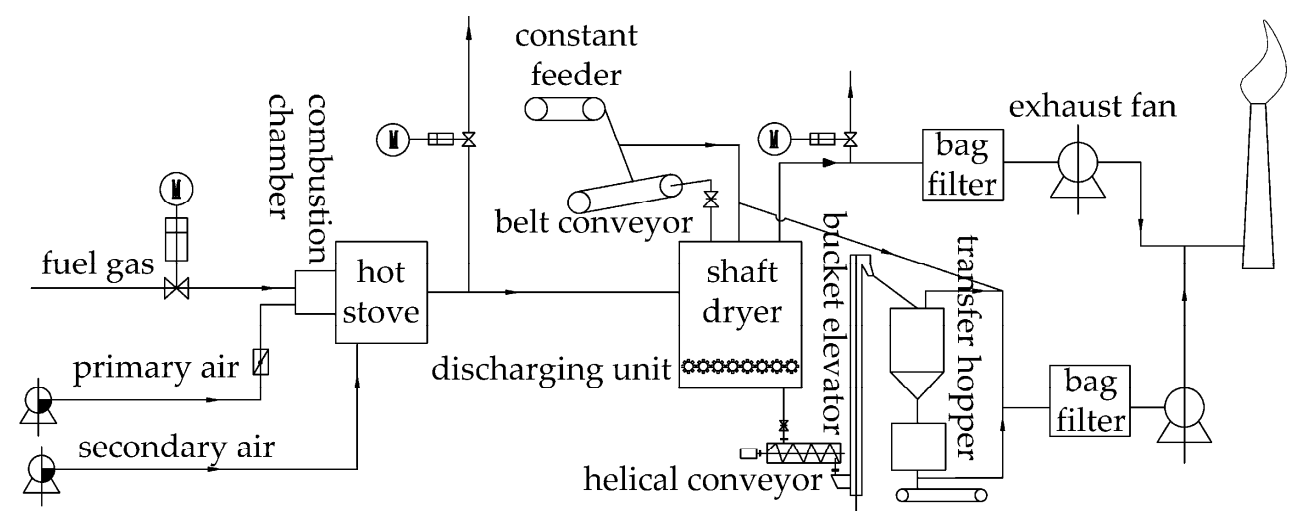

Figure 1. Scheme of the green coke drying system.

Figure 2 depicts the layout of the shaft dryer. The shaft dryer is principally based on the moving bed technology $[38,39]$. With medium-temperature gas as the heat source, the refractory material can be totally saved, and the over-burnt and pollution caused by the spalled refractory material can be avoided. The wet green cokes are uniformly placed in the shaft dryer and discharged by gravity. Thus, the mechanical transmission unit can be removed, resulting in the low failure of the system. In addition, because no pneumatic conveying of the green cokes occurs inside the shaft dryer, hence there is no need to crush the green cokes to meet a strict limitation of the particle size.

A 20,000 t/y shaft dryer is selected as a case analysis. The dryer runs $300 \mathrm{~d} / \mathrm{y}$ and $24 \mathrm{~h} / \mathrm{d}$. The initial moisture is $10 \%$, and the final moisture is $1 \%$. The target temperature of dried green cokes is $80^{\circ} \mathrm{C}$, and the flow rate of flue gas is $5000 \mathrm{~m}^{3} / \mathrm{h}$. The average specific heat capacities of green cokes and flue gas are 0.808 and $1.4 \mathrm{~kJ} /\left(\mathrm{kg} .{ }^{\circ} \mathrm{C}\right)$, respectively. It can be calculated that the energy efficiency is $80 \%$. Given the influence of heat loss, the estimated that an energy efficiency of $65 \%-75 \%$ could be achieved in practice. The corresponding economic and environmental assessment [40] can also be conduction based on the design parameters. The characteristics of the novel shaft dryer can be summarized as follows:

- It has a simple structure and no mechanical transmission unit, making it easy to maintain, with low noise while operating and low failure rates. 
- It is a wholly-sealed system, and thus the energy efficiency can be as high as $65 \%-75 \%$ with no leak of environmental pollutants.

- It can be built by using less metal, less land area, lower capital investment cost, compared with other drying methods.

- It uses medium-temperature gas as the heat source, which will not cause the over-burnt quality of green cokes.

- It does not need liner inside the shaft dryer, ensuring that final green cokes have good quality.

- It has a low breakage rate of green coke because of the low-speed flow of green coke inside the shaft dryer, which further reduces the amount of dust and the cost of environmental assets.

- It can easily adjust the residence time and the resultant moisture content of green cokes.

- It has less strict requirement on the particle size of green cokes because of the use of gravity discharging and related units.

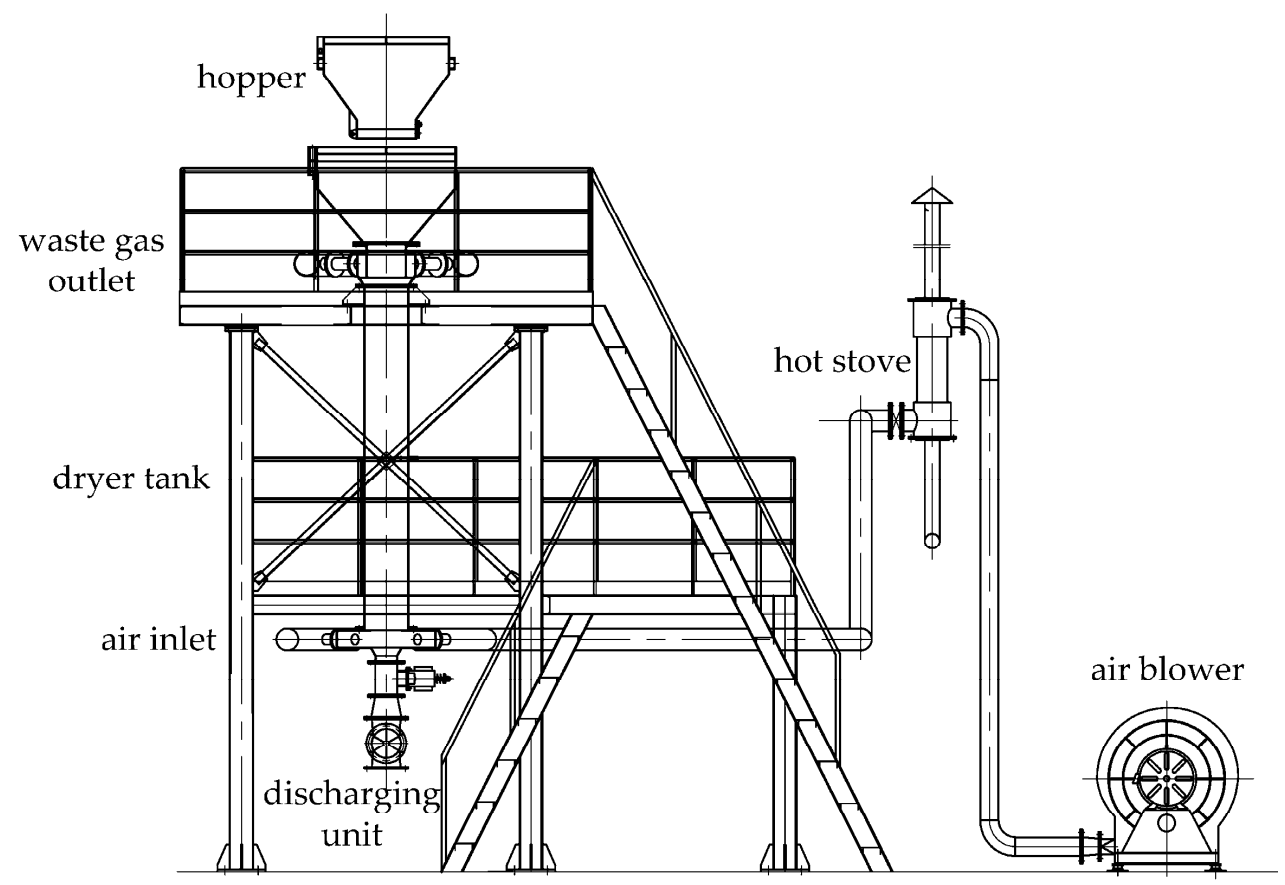

Figure 2. Scheme of shaft dryer.

\section{Materials and Experimental Methods}

As a novel dryer, the shaft dryer can be quantitatively designed based on the characteristics of green cokes, which affect the structural and operational parameters of the dryer [36]. Most importantly, the particle size distribution and pressure drop scheme determine the selection of air blowers and the affiliated motors. The initial moisture content determines the residence time of the green cokes and the speed of the discharging unit and the helical conveyor. The vertex angle of pile affects the design of the distributor of the shaft dryer. The discharge characteristics of the toothed roller are determined by the productivity of upstream processes. To provide more detailed data to fill in the gap between concept and application, the following experiments are conducted in this work.

\subsection{Materials}

The particle size of green cokes discharged from the delayed coking process is less than $70 \mathrm{~mm}$, which can be charged into the shaft dryer directly without any further processing. Thus, in this work, 10-, 30-, and 50-mm meshes were used for the screening of green cokes. The particle size distribution of green cokes used as the raw material in this work are shown in Table 2. 
Table 2. Particle size distribution of green cokes.

\begin{tabular}{|c|c|c|c|c|c|}
\hline $\begin{array}{l}\text { Test } \\
\text { No. }\end{array}$ & $\begin{array}{l}\text { Percentage of Size } \\
(0,10) \mathrm{mm}(\%)\end{array}$ & $\begin{array}{l}\text { Percentage of Size } \\
{[10,30) \mathrm{mm}(\%)}\end{array}$ & $\begin{array}{c}\text { Percentage of Size } \\
{[30,50) \mathrm{mm}(\%)}\end{array}$ & $\begin{array}{c}\text { Percentage of Size } \\
{[50,70] \mathrm{mm}(\%)}\end{array}$ & $\begin{array}{c}\text { Median } \\
\text { Size }(\mathrm{mm})\end{array}$ \\
\hline 1 & 37 & 26 & 12 & 25 & 26.85 \\
\hline 2 & 32 & 25 & 17 & 26 & 29.00 \\
\hline 3 & 33 & 23 & 11 & 33 & 30.45 \\
\hline 4 & 32 & 20 & 13 & 35 & 31.80 \\
\hline
\end{tabular}

\subsection{Experimental Methods}

\subsubsection{Method to Determine the Initial Moisture Content}

A weighing bottle was used to weigh a certain mass of wet green coke. After a 5-min preheating of an oven at $110^{\circ} \mathrm{C}$, the weighing bottle was uncovered and put in the drying oven for $2 \mathrm{~h}$. Then, the weighing bottle was taken out, immediately covered with its lid, and put in a desiccator until it cools to indoor temperature. Finally, a desiccation check was conducted for $30 \mathrm{~min}$. The initial moisture content can be calculated by

$$
\omega=\frac{m_{0}-m_{1}}{m_{0}} \times 100 \%,
$$

where $\omega$ is the initial moisture content, $\% ; m_{0}$ and $m_{1}$ are the mass of green cokes before and after the drying experiment, respectively, measured in $\mathrm{g}$.

\subsubsection{Method to Determine the Vertex Angle of Pile of Green Cokes}

When green cokes are poured on a surface, they usually form a conical pile. The angle that the surface of the pile of green cokes makes with vertical is referred to as the half-vertex angle. The vertex angle of pile is very important to design the structure of the green coke distributor of the shaft dryer. As shown in Figure 3, the vertical height and hypotenuse can be measured by using a ruler. Then, the vertex angle of the pile can be calculated by

$$
\alpha=2 \cdot \arccos (h / l) .
$$

where $\alpha$ is the vertex angle of the piles of green cokes, $h$ is the vertical height, and $l$ is the hypotenuse.

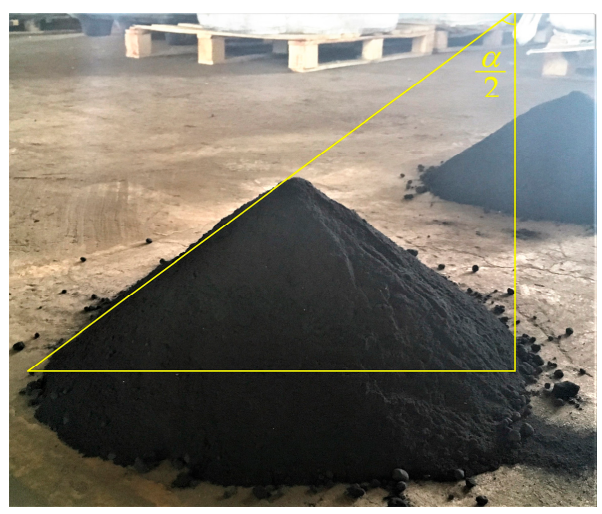

Figure 3. Measuring the vertex angle of piles of green cokes.

\subsubsection{Method to Determine the Pressure Drop Characteristics}

The air blower is a component of this proposed drying system and its capacity and operating parameters significantly influence the gas flow and heat transfer inside the shaft dryer. A pressure drop experiment was also conducted in this work by using an apparatus shown in Figure 4 . The diameter of 
this apparatus is $800 \mathrm{~mm}$. Wet green cokes were filled in the dryer tank, and the packing height was $1500 \mathrm{~mm}$ above the air inlet pipe. The outer and inner diameters of the air inlet pipe are $219 \mathrm{~mm}$ and $200 \mathrm{~mm}$, respectively. The pressure drop was measured by using a differential pressure transmitter, and the flow rate of air was measured by a gas flowmeter.

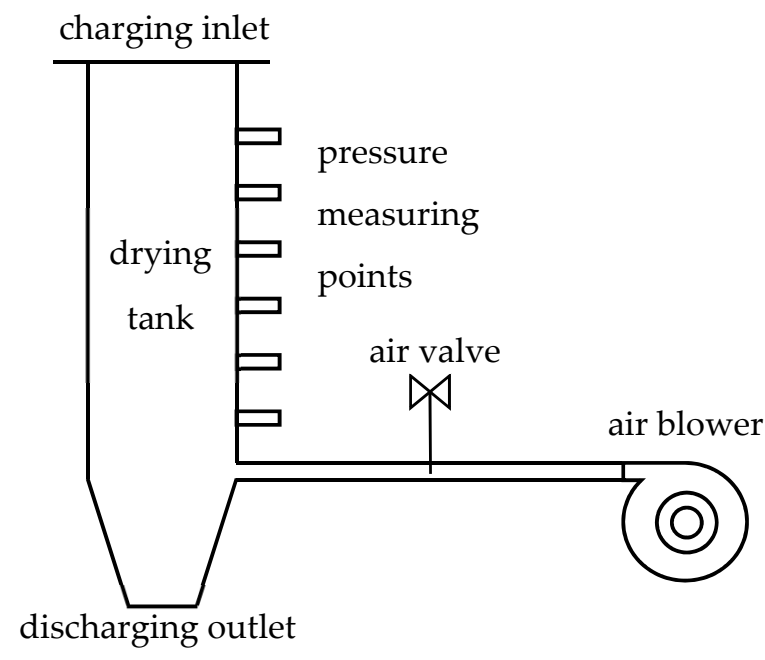

(a)

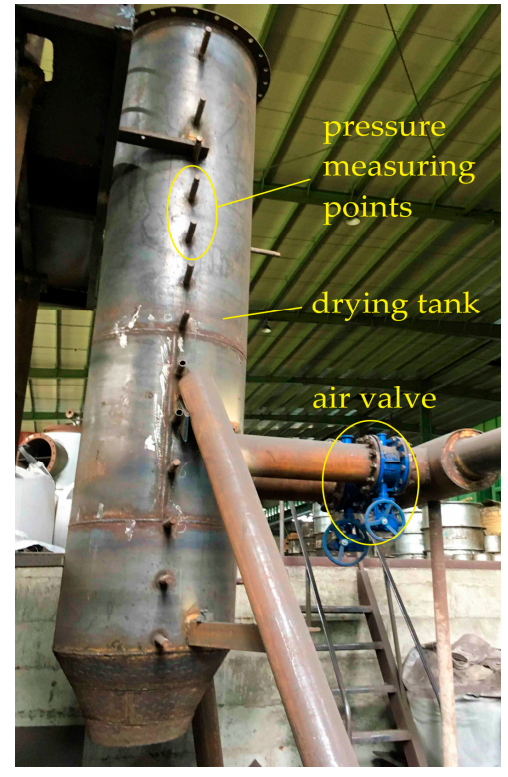

(b)

Figure 4. Apparatus for pressure drop experiment: (a) Conceptual scheme; (b) Real apparatus.

\subsubsection{Method to Determine the Discharge Characteristics of the Toothed Roller}

The toothed roller is specially designed for discharging the final green cokes. It is used for controlling the discharge speed of green cokes. Thus, in this work, the rational tooth spacing and rotary speed were experimentally investigated as shown in Figure 5.

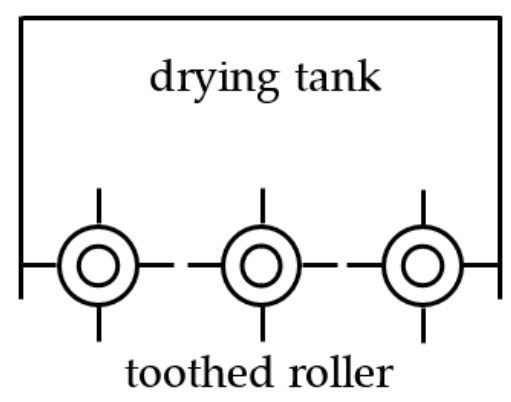

(a)

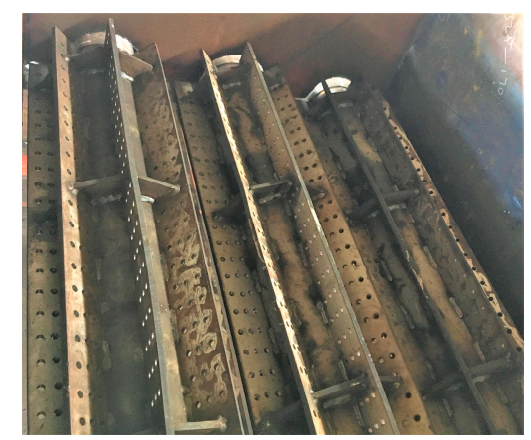

(b)

Figure 5. Apparatus for discharging experiment: (a) Conceptual scheme; (b) Real apparatus.

The green cokes' leakage can be measured as follows. The minimum tooth spacing was set as $30 \mathrm{~mm}$, and the distance between the rollers and the top of the green coke stock was $1500 \mathrm{~mm}$. The green cokes whose particle size is larger than $30 \mathrm{~mm}$ were screened out, and the left ones smaller than $30 \mathrm{~mm}$ were hung to $3 \mathrm{~m}$ above the experimental apparatus. After discharging, the green coke leakage was weighed. The experiment can be repeated by adjusting the minimum tooth spacing to 10 and $20 \mathrm{~mm}$. 


\section{Results and Discussions}

Figure 6 shows three kinds of green coke with different size at the initial moisture content of $22 \%$. As the moisture content relates to the granulation properties [41], the lump, fine, and mixed green coke particles with the median size of 35.0, 1.0, and $21.4 \mathrm{~mm}$, respectively, were selected in this experiment. For mixed green coke, the lump green coke accounts for $60 \%$. Figure 7 shows the relationship between moisture content and gas temperature. With the increase in gas temperature, the moisture content reduces remarkably. For drying gas at $350{ }^{\circ} \mathrm{C}$, the moisture content of lump green coke was $6.82 \%$, while that of fine and mixed green cokes could be as low as $1.38 \%$ and $0.40 \%$, respectively. Though lump green coke can be dried by using this shaft dryer, it may consume more energy. It can be found that the mixed green coke has the lowest moisture content because this plan has the best gas flow and heat transfer effect. Thus, mixed green coke is a good option in the real drying process.

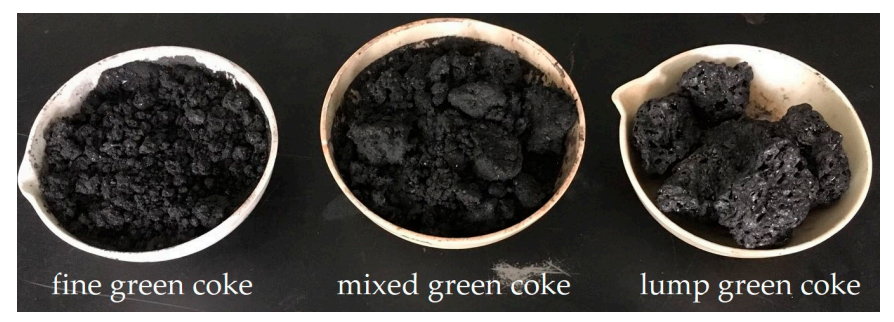

Figure 6. Three different green cokes used in the experiment.

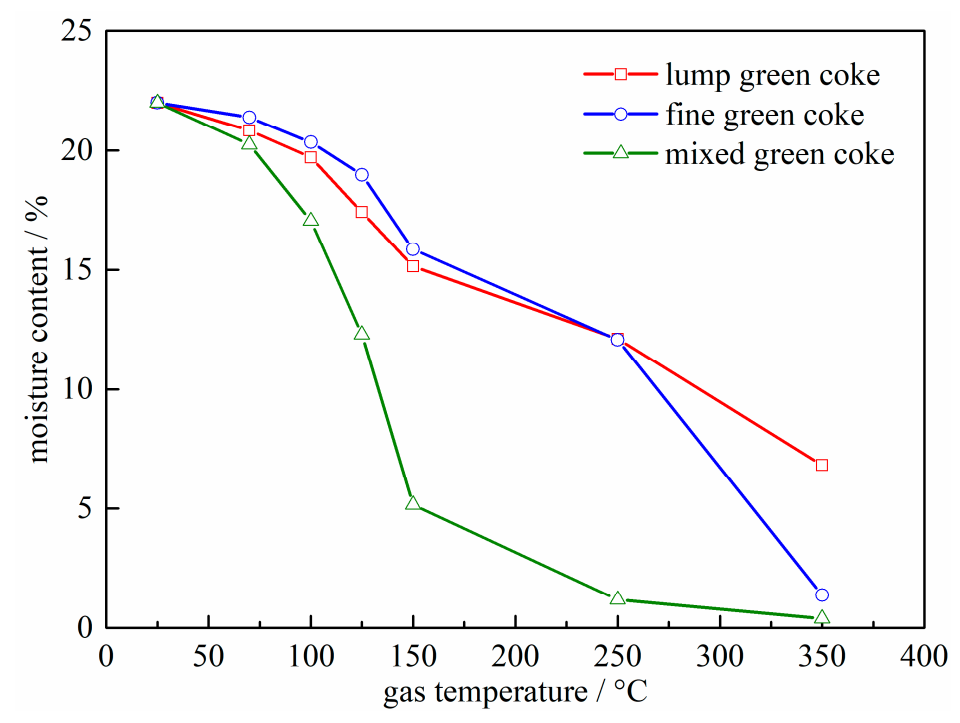

Figure 7. Relationship between moisture content and gas temperature.

Table 3 lists the measurement data and results of the vertex angle of the pile of green cokes of five reduplicative experiments. The vertex angle of the pile is another key property of coke besides the particle size distribution and strength [42]. It is shown that the average vertex angle of pile of green cokes is $109.2^{\circ}$, which is very important to design the structure of the distributor.

Table 3. Results of vertex angle of the pile of green cokes.

\begin{tabular}{cccc}
\hline No. & Vertical Height $(\mathbf{m m})$ & Hypotenuse $(\mathbf{m m})$ & Vertex Angle $\left.\mathbf{(}^{\circ}\right)$ \\
\hline 1 & 314 & 556 & 112 \\
2 & 283 & 477 & 108 \\
3 & 287 & 495 & 110 \\
4 & 283 & 470 & 106 \\
5 & 284 & 495 & 110 \\
\hline
\end{tabular}


To investigate the pressure drop characteristics of green cokes, a fixed bed experiment was conducted. Four sets of green cokes as shown in Table 2 were used in this experiment. The relationship between the pressure drop and bed height is shown in Figure 8. An approximately linear relationship is shown and the pressure drop increases with the increase in bed height. The pressure characteristics vary with the particle sizes [43]. The green coke with larger size has a less pressure drop, because of its relatively large void ratio and good gas flow behavior. When the bed height is $1250 \mathrm{~mm}$, the total pressure drops of the four test sets with median green coke size of 26.85, 29.00,30.45, and $31.80 \mathrm{~mm}$ are 6104, 5944, 5744, and $5504 \mathrm{~Pa}$, respectively. It can be found from Figure 9 that the specific pressure drops of the four test sets are $5714,5554,5354$, and $5114 \mathrm{~Pa} / \mathrm{m}$, respectively.

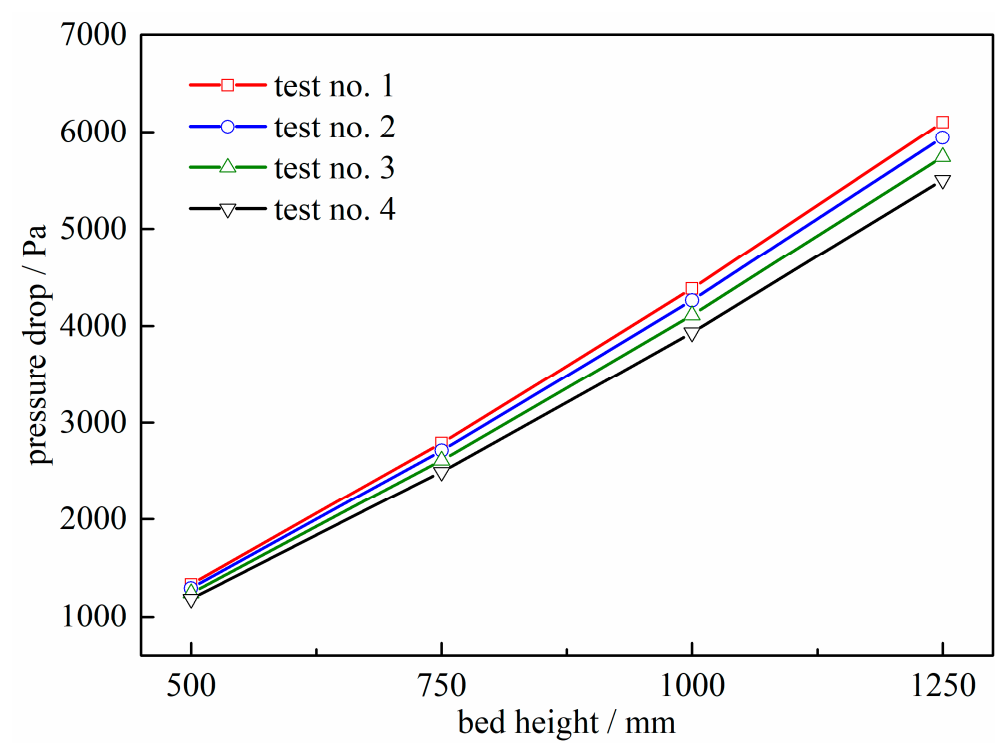

Figure 8. Relationship between pressure drop and bed height. Test no. refers to that listed in Table 2.

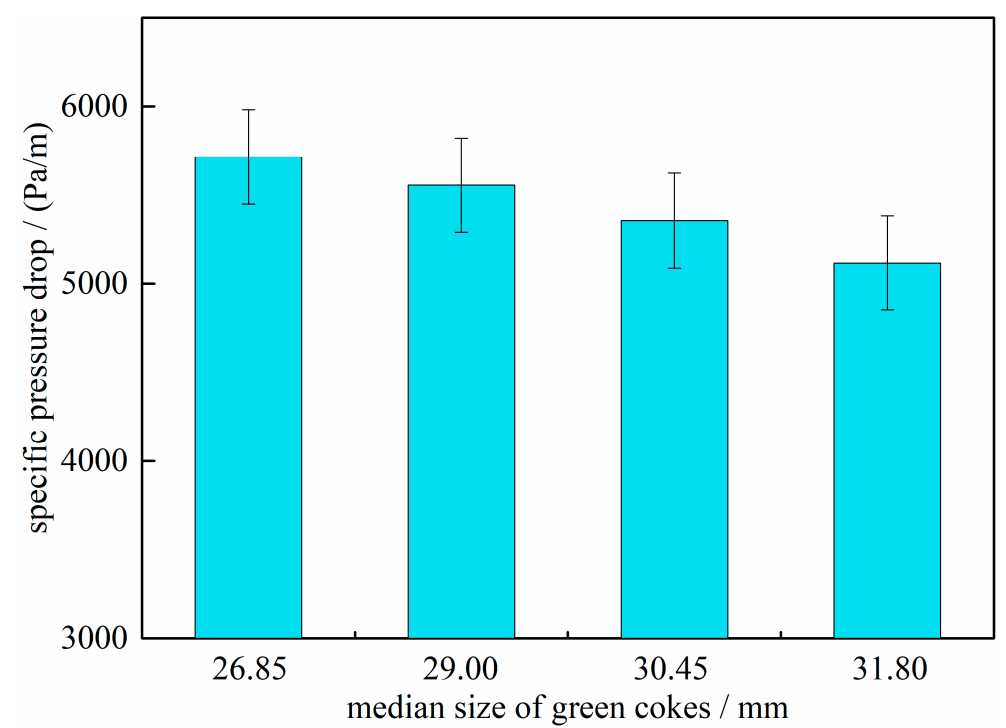

Figure 9. Relationship between specific pressure drop and green coke size.

Figure 10 shows the relationship between the mass of green coke leakage and tooth spacing based on the results of five repeated experiments. It can be seen that the green coke leakage increases with the increase in tooth spacing. Given that the rolls may experience a horizontal movement because of the axial compression among green cokes when discharging, the initial green coke leakage should be 
small and adjusted to its reasonable leakage tardily. The optimal tooth spacing can be determined according to the requirement of production yield.

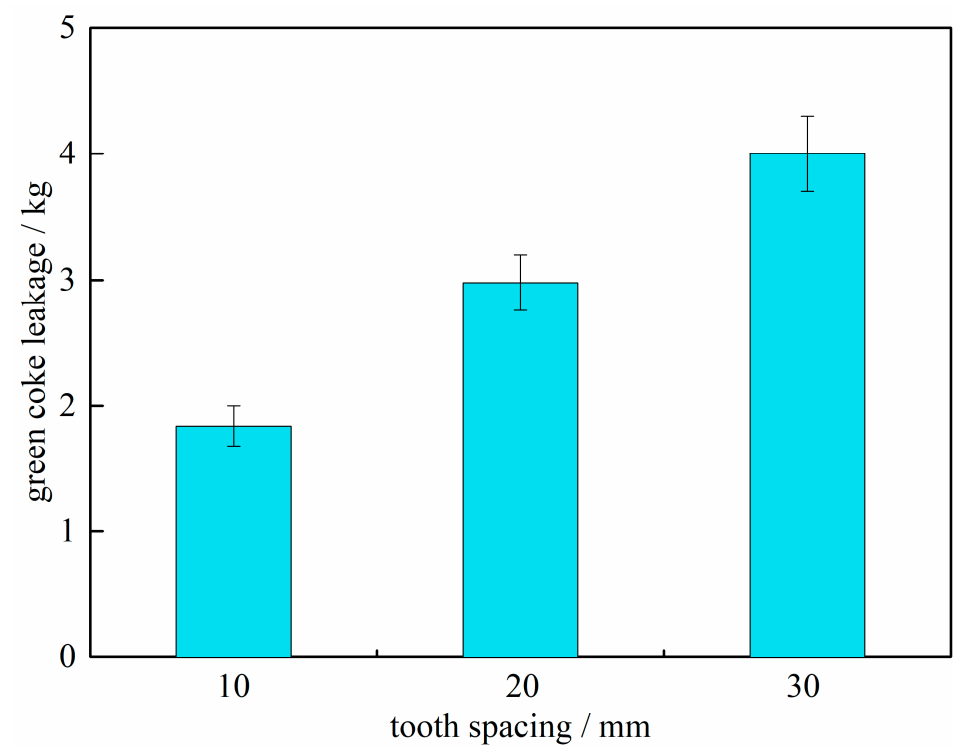

Figure 10. Relationship between green coke leakage and tooth spacing.

The optimal rotary speed can be determined as follows. The mixed green cokes with the maximum particle size as $70 \mathrm{~mm}$ were filled in the drying tank. The rolls horizontally set in the shaft dryer were rotated by $180^{\circ}$ at a constantly rotary speed. After discharging, the green coke leakage was weighed. Then, the rotary speed of the rollers can be obtained by the mass of leakage and the required leakage per minute in real production. With the development of Industrial 4.0 [44], the tooth spacing and rotary speed of the rollers can be adjusted according to the present working conditions.

\section{Conclusions}

(1) A novel drying system and a shaft dryer are proposed for drying the wet coal-based green needle cokes by using medium-temperature gas as a heat source in an energy-efficient, direct-contact, and counter-current way.

(2) The moisture content of green cokes reduces remarkably with the increase in gas temperature. Compared with lump and fine green cokes, mixed green coke has the lowest moisture content and is recommended in the real drying process. The average vertex angle of the pile of green cokes is $109.2^{\circ}$, which is an important parameter for the structure of the shaft dryer distributor.

(3) An approximately linear relationship is gotten between the pressure drop and the green coke bed height. The green coke with larger size has a less pressure drop. The specific pressure drops of the four test sets with median green coke size of 26.85, 29.00, 30.45, and $31.80 \mathrm{~mm}$ are 5714, 5554, 5354, and $5114 \mathrm{~Pa} / \mathrm{m}$, respectively.

(4) Tooth spacing affects the mass of green coke leakage. The larger the spacing, the more the leakage. In real production, the optimal tooth spacing and rotary speed of the rollers should be determined by the required production yield.

Author Contributions: Conceptualization, G.X., X.Z. and J.C.; methodology, G.X.; validation, G.X., K.Z. and S.Z.; formal analysis, G.X. and W.S.; investigation, K.Z. and S.Z.; data curation, G.X.; writing-original draft preparation, W.S. and G.X.; writing-review and editing, W.S. and G.X.; visualization, W.S.; supervision, X.Z. and J.C.; project administration, G.X.; funding acquisition, G.X.

Funding: This research was funded by the National Key R\&D Program of China, grant number 2017YFB0603502; the National Natural Science Foundation of China, grant number 51734004; and the Liaoning Revitalization Talents Program, grant number XLYC1805016.

Conflicts of Interest: The authors declare no conflict of interest. 


\section{References}

1. Halim, H.P.; Im, J.S.; Lee, C.W. Preparation of needle coke from petroleum by-products. Carbon Lett. 2013, 14, 152-161. [CrossRef]

2. Wang, R.; Lu, G.; Qiao, W.; Yu, J. Catalytic graphitization of coal-based carbon materials with light rare earth elements. Langmuir 2016, 32, 8583-8592. [CrossRef] [PubMed]

3. Ma, S.; Zhang, Y.; Lv, J.; Yang, H.; Wu, J. Energy-cyber-physical system enabled management for energy-intensive manufacturing industries. J. Clean. Prod. 2019, 226, 892-903. [CrossRef]

4. Wang, J.; Gu, F.; Liu, Y.; Fan, Y.; Guo, J. Bidirectional interactions between trading behaviors and carbon prices in European Union emission trading scheme. J. Clean. Prod. 2019, 224, 435-443. [CrossRef]

5. Guo, J.; Su, B.; Yang, G.; Feng, L.; Liu, Y.; Gu, F. How Do Verified Emissions Announcements Affect the Comoves between Trading Behaviors and Carbon Prices? Evidence from EU ETS. Sustainability 2018, 10, 3255. [CrossRef]

6. Lv, J.; Gu, F.; Zhang, W.; Guo, J. Life cycle assessment and life cycle costing of sanitary ware manufacturing: A case study in China. J. Clean. Prod. 2019, 238, 117938. [CrossRef]

7. Li, X.; Sun, W.; Zhao, L.; Cai, J. Emission characterization of particulate matter in the ironmaking process. Environ. Technol. 2019, 40, 282-292. [CrossRef]

8. Zhao, L.; Sun, W.; Li, X.; Ye, Z.; Huang, J.; Zhang, G.; Cai, J. Assessment of particulate emissions from a sinter plant in steelmaking works in China. Environ. Monit. Assess. 2017, 189, 368. [CrossRef]

9. Xu, X.; Li, K.; Jia, H.; Yu, X.; Deng, J.; Mu, Y. Data-driven dynamic modeling of coupled thermal and electric outputs of microturbines. IEEE Trans. Smart Grid 2016, 9, 1387-1396. [CrossRef]

10. Sun, W.; Wang, Y.; Zhang, F.; Zhao, Y. Dynamic allocation of surplus byproduct gas in steel plant by dynamic programming with reduced state space algorithm. Eng. Optim. 2018, 50, 1578-1592. [CrossRef]

11. Sun, W.; Xu, X.; Lv, Z.; Mao, H.; Wu, J. Environmental impact assessment of wastewater discharge with multi-pollutants from iron and steel industry. J. Environ. Manag. 2019, 245, 210-215. [CrossRef]

12. Li, X.; Sun, W.; Zhao, L.; Cai, J. Material metabolism and environmental emissions of BF-BOF and EAF steel production routes. Miner. Process. Extr. Metall. Rev. 2018, 39, 50-58. [CrossRef]

13. Zubi, G.; Dufo-López, R.; Carvalho, M.; Pasaoglu, G. The lithium-ion battery: State of the art and future perspectives. Renew. Sustain. Energy Rev. 2018, 89, 292-308. [CrossRef]

14. Zhu, Y.; Zhao, C.; Xu, Y.; Hu, C.; Zhao, X. Preparation and Characterization of Coal Pitch-Based Needle Coke (Part I): The Effects of Aromatic Index (fa) in Refined Coal Pitch. Energy Fuels 2019, 33, 3456-3464. [CrossRef]

15. Kondrasheva, N.K.; Rudko, V.A.; Nazarenko, M.Y.; Povarov, V.G.; Derkunskii, I.; Konoplin, R.; Gabdulkhakov, R. Influence of parameters of delayed coking process and subsequent calcination on properties and morphology petroleum needle coke from decant oil mixture of west Siberian oil. Energy Fuels 2019, 33, 6373-6379. [CrossRef]

16. Hardin, E.E.; Ellis, P.J.; Beilharz, C.L.; McCoy, L. A Comprehensive Review of the Effects of Calcination at Various Temperatures on Coke Structure and Properties Part II. In Essential Readings in Light Metals; Springer Science and Business Media LLC: Cham, Switzerland, 2016; Volume 4, pp. 73-83.

17. Wang, Y.H.; Zhao, L.; Sun, W.Q.; Ye, Z.; Cai, J.J. Characteristics of particulate matter emissions from the coking process. Environ. Sci. 2018, 39, 5359-5364.

18. Zhang, W.; Gu, F.; Guo, J. Can smart factories bring environmental benefits to their products? A case study of household refrigerators. J. Ind. Ecol. 2019. [CrossRef]

19. Sun, W.; Xu, X.; Wu, J. Chlorine corrosion of blast furnace gas pipelines: Analysis from thermal perspective. J. Min. Met. Sect. B Met. 2019, 55, 197-208. [CrossRef]

20. Liu, C.; Sang, S.; Zhang, K.; Song, F.; Wang, H.; Fan, X. Effects of temperature and pressure on pore morphology of different rank coals: Implications for $\mathrm{CO}_{2}$ geological storage. J. CO2 Util. 2019, 34, 343-352. [CrossRef]

21. Zhang, W.; Guo, J.; Gu, F.; Gu, X. Coupling life cycle assessment and life cycle costing as an evaluation tool for developing product service system of high energy-consuming equipment. J. Clean. Prod. 2018, 183, 1043-1053. [CrossRef]

22. Alonso, E.; Gallo, A.; Roldán, M.; Pérez-Rábago, C.; Fuentealba, E. Use of rotary kilns for solar thermal applications: Review of developed studies and analysis of their potential. Sol. Energy 2017, 144, 90-104. [CrossRef] 
23. Hernández, D.; Quinteros-Lama, H.; Tenreiro, C.; Gabriel, D. Assessing Concentration Changes of Odorant Compounds in the Thermal-Mechanical Drying Phase of Sediment-Like Wastes from Olive Oil Extraction. Appl. Sci. 2019, 9, 519. [CrossRef]

24. Eremin, A.Y.; Stakheev, S.G.; Zagainov, N.V. Drying of coking batch by means of secondary energy resources. Coke Chem. 2017, 60, 185-188. [CrossRef]

25. Yannick, E.R.; Abraham, T.F.; Marcel, E.; Alexis, K. Experimental Study of the Drying Kinetics of Mango (mangifera indica L.) during Airflow Drying Licking Countercurrent. Am. J. Food Sci. Technol. 2019, 7, 127-132. [CrossRef]

26. Si, C.; Wu, J.; Wang, Y.; Zhang, Y.; Shang, X. Drying of Low-Rank Coals: A Review of Fluidized Bed Technologies. Dry. Technol. 2015, 33, 277-287. [CrossRef]

27. Liu, C.-H.; Zhang, L.-B.; Srinivasakannan, C.; Peng, J.-H.; Liu, B.-G.; Xia, H.-Y. Dielectric Properties and Optimization of Parameters for Microwave Drying of Petroleum Coke Using Response Surface Methodology. Dry. Technol. 2014, 32, 328-338. [CrossRef]

28. Pang, M.; Peng, Y.; Zhou, P.; Du, Y. Thermodynamic modeling of the Hf-N system. J. Min. Met. Sect. B Met. 2018, 54, 111-118. [CrossRef]

29. Lecompte, S.; Ntavou, E.; Tchanche, B.; Kosmadakis, G.; Pillai, A.; Manolakos, D.; De Paepe, M. Review of Experimental Research on Supercritical and Transcritical Thermodynamic Cycles Designed for Heat Recovery Application. Appl. Sci. 2019, 9, 2571. [CrossRef]

30. Saucedo-Zendejo, F.; Reséndiz-Flores, E. Transient heat transfer and solidification modelling in direct-chill casting using a generalized finite differences method. J. Min. Met. Sect. B Met. 2019, 55, 47-54. [CrossRef]

31. Sun, W.Q.; Yue, X.Y.; Wang, Y.H.; Cai, J.J. Energy and exergy recovery from exhaust hot water using ORC (organic Rankine cycle) and a retrofitted configuration. J. Cent. South Univ. 2018, 25, 1464-1474. [CrossRef]

32. Sun, W.; Zhou, Y.; Lv, J.; Wu, J. Assessment of multi-air emissions: Case of particulate matter (dust), $\mathrm{SO}_{2}$, $\mathrm{NO}_{x}, \mathrm{CO}_{2}$ from iron and steel industry of China. J. Clean. Prod. 2019, 232, 350-358. [CrossRef]

33. Wang, Z.; Wang, F.; Zhu, Y.; Gong, B. Method of Desulfurization Process Selection Based on Improved Fuzzy Comprehensive Evaluation: A Case Study of Papermaking Desulfurization in China. Processes 2019, 7, 446. [CrossRef]

34. Liu, J.; Yu, Q.; Zuo, Z.; Yang, F.; Han, Z.; Qin, Q. Reactivity and performance of dry granulation blast furnace slag cement. Cem. Concr. Compos. 2019, 95, 19-24. [CrossRef]

35. Matiukhin, V.; Yaroshenko, Y.; Bulatov, K. On Modernization of Air Supply Systems for Improvement of Gas Distribution in Shaft Furnaces. Solid State Phenom. 2018, 284, 1390-1397. [CrossRef]

36. Ozgen, F.; Celik, N. Evaluation of design parameters on drying of kiwi fruit. Appl. Sci. 2019, 9, 10. [CrossRef]

37. Al-Kassir, A.; Coelho, P.; Garcia-Sanz-Calcedo, J.; Moral, F.J.; Al-Karany, R.K.; Yusaf, T. An Experimental Technology of Drying and Clean Combustion of Biomass Residues. Appl. Sci. 2018, 8, 905. [CrossRef]

38. Prabakar, D.; Manimudi, V.T.; Mathimani, T.; Kumar, G.; Rene, E.R.; Pugazhendhi, A. Pretreatment technologies for industrial effluents: Critical review on bioenergy production and environmental concerns. J. Environ. Manag. 2018, 218, 165-180. [CrossRef]

39. De Castro, J.A.; De Oliveira, E.M.; De Campos, M.F.; Takano, C.; Yagi, J.-I. Analyzing cleaner alternatives of solid and gaseous fuels for iron ore sintering in compacts machines. J. Clean. Prod. 2018, 198, 654-661. [CrossRef]

40. Zhang, W.; Gu, F.; Dai, F.; Gu, X.; Yue, F.; Bao, B. Decision framework for feasibility analysis of introducing the steam turbine unit to recover industrial waste heat based on economic and environmental assessments. J. Clean. Prod. 2016, 137, 1491-1502. [CrossRef]

41. Prasai, T.P.; Walsh, K.B.; Midmore, D.J.; Jones, B.E.; Bhattarai, S.P. Manure from biochar, bentonite and zeolite feed supplemented poultry: Moisture retention and granulation properties. J. Environ. Manag. 2018, 216, 82-88. [CrossRef]

42. Shiau, J.-S.; Ko, Y.-C.; Ho, C.-K.; Hung, M.-T. Results of tuyere coke sampling with regard to application of appropriate coke strength after reaction (CSR) for a blast furnace. J. Min. Met. Sect. B: Met. 2017, 53, 131-138. [CrossRef] 
43. Ali, S.S.; Basu, A.; Alfadul, S.M.; Asif, M. Nanopowder Fluidization Using the Combined Assisted Fluidization Techniques of Particle Mixing and Flow Pulsation. Appl. Sci. 2019, 9, 572. [CrossRef]

44. Gu, F.; Guo, J.; Hall, P.; Gu, X. An integrated architecture for implementing extended producer responsibility in the context of Industry 4.0. Int. J. Prod. Res. 2019, 57, 1458-1477. [CrossRef]

(C) 2019 by the authors. Licensee MDPI, Basel, Switzerland. This article is an open access article distributed under the terms and conditions of the Creative Commons Attribution (CC BY) license (http://creativecommons.org/licenses/by/4.0/). 